\title{
Arbuscular mycorrhizal and dark septate fungi are not common in roots of epiphytic pteridophytes of a transitional forest area in South Brazil
}

\author{
Heloisa Krzyzanski ${ }^{1 *}$ (D), Maria Auxiliadora Milaneze Gutierre ${ }^{2}$ (1) and Rosilaine Carrenho ${ }^{2}$ (1)
}

Received: August 22, 2020

Accepted: March 8, 2021

\begin{abstract}
Arbuscular mycorrhizal fungi (AMF) and dark septate fungi (DSF) are symbionts that are associated with the roots of plants, including epiphytic lycophytes and ferns. Paris-type mycorrhiza and glomoid structures are the most common forms of colonization in these plants. This work aimed to evaluate the occurrence of these symbionts in the roots of epiphytic lycophytes and ferns as well as the diversity of AMF spores recovered from substrate associated with the roots of eleven species. Roots of Asplenium gastonis, Campyloneurum aglaolepis, C. nitidum, Niphidium crassifolium, Pecluma pectinatiformis, Phlegmariurus mandiocanus, Pleopeltis hirsutissima, P. pleopeltifolia and Selaginella microphylla had hyphae and vesicles typical of AMF colonization, but not arbuscules. Campyloneurum nitidum, Pecluma pectinatiformis, Phlegmariurus mandiocanus, Pleopeltis pleopeltifolia and Selaginella microphylla had melanized hyphae and microsclerotia typical of DSF. All species colonized by DSF were also colonized by AMF. Seventeen spore morphotypes of AMF were identified, of which six were acaulosporoid and eleven glomoid. Glomus aff. formosanum and Acaulospora aff. lacunosa were the most abundant and frequent species. Epiphytic lycophytes and ferns host concurrently AMF and DSF but colonization is scanty in their roots. For the first time, acaulosporoid spores and intraradical vesicles are reported for this group of plants.
\end{abstract}

Keywords: ferns, Glomeromycotina, lycophytes, mixed rain forest, native species, semideciduous forest

\section{Introduction}

In the forest, the light gradient is vertically stratified and some epiphytic species are exposed to high radiation while others grow in almost complete shade (Graham \& Andrade 2004). Epiphytes have several adaptations for storing water and nutrients that enable them to occupy the forest canopy, including pseudobulbs (Orchidaceae), succulent roots, stems and leaves (Gesneriaceae, Piperaceae, Cactaceae, Orchidaceae), velamen (Orchidaceae, Araceae), and water-storing leaf rosettes (Bromeliaceae). Some ferns are poikilohydric (Hymenophyllaceae; Pleopeltis), others are covered with scales to reduce evapotranspiration (Fraga et al. 2008).

Arbuscular mycorrhizae occur in roots of angiosperms and gymnosperms, as well as some bryophytes, lycophytes and ferns (Souza et al. 2010), and are recognized as being responsible for the conquest of land (Remy et al. 1994; Taylor et al. 1995). In this type of association, more than one species of fungus can colonize the roots, and a single species of mycorrhizal fungi can colonize more than one plant species, separately or simultaneously (Chilvers et al. 1987; Wagg et al. 2008).

1 Programa de Pós-Graduação em Biologia Comparada, Universidade Estadual de Maringá, 87020-900, Maringá, PR, Brazil

2 Departamento de Biologia, Universidade Estadual de Maringá, 87020-900, Maringá, PR, Brazil

* Corresponding author: helo_d.k@hotmail.com 
Unlike what has been observed in terrestrial plants, where arbuscular mycorrhizal symbiosis is extremely common, the biological importance of this in plants occupying other niches is less clear. The epiphytic habitat poses different demands to plants compared to the terrestrial habitat and the slow growth rate in lycophytes and ferns (Nervo et al. 2019) should affect the relationship with the fungi. For forest epiphytes that naturally grow below the canopy, where there is less light, access to water depends on rainfall and relative humidity, and the availability of inorganic nutrients is influenced by morphological and chemical properties of the bark of the host tree (Reinert 1998).

Arbuscular mycorrhizal structures (Paris and intermediate morphotypes) have been observed in both the roots and gametophytes of lycophytes and ferns, which help them obtain water and mineral nutrients from environment (Muthukumar \& Prabha 2013; Muthukumar et al. 2014). The leptosporangiate ferns are less dependent on symbiosis than those of early-diverging lineages are, and epiphytic species are unlikely hosts for mycorrhizal fungi because of the environment where they grow (Gemma et al. 1992; Lehnert et al. 2009). Despite that, colonization may reach percentages close to $60 \%$ and $80 \%$ in ferns and lycophytes, respectively (Muthukumar \& Prabha 2013; Muthukumar et al. 2014; Muthuraja et al. 2014).

Like mycorrhizal fungi, another group of common root symbiotic fungi, the dark septate fungi (DSF), presumably affects their hosts in various ways (Jumpponen 2001). These fungi have intense dark pigmentation and form septate hyphae and microesclerotia that grow inter- and intracellularly in the plant cortex (Barrow \& Aaltonen 2001). These fungi are widely distributed, are common in harsh environments, and may occur as saprophytic, mutualistic symbiotic or pathogenic species (Barrow \& Aaltonen 2001; Mandyam \& Jumpponen 2005).

Mixed colonization of DSF and AMF are common in land vascular plants (Fuchs \& Haselwandter 2004; Cázares et al. 2005; Muthukumar et al. 2006; Postma et al. 2007; Muthukumar et al. 2014). Some authors suggest that DSF can establish associations similar to mycorrhizal fungi, acting as promoters of plant growth, especially by facilitating the absorption of nutrients like phosphorus and nitrogen (Scervino et al. 2009; Chen et al. 2010), including the production of extracellular enzymes capable of hydrolyzing complex compounds of carbon, nitrogen and phosphorus (Mandyam \& Jumpponen 2005). Additionally, it has been suggested that the melanization of fungal cell walls and consequent production of dark hyphae, could be a factor that contributes to the adaptation and survival of the host plant under adverse or stressful conditions, since the melanin would play an important role in elimination of oxygen radicals generated during abiotic stress (Redman et al. 2002).

Knowledge about interactions between roots of epiphytic lycophytes and ferns and fungi is yet fragmentary because most of the studies was made in a few localities around the world and analysed a small number of species. Therefore, this study aims to evaluate the occurrence of AMF and DSF in roots of epiphytic lycophytes and ferns from a forest fragment of an ecotonal region (mixed rain forest and semideciduous forest). In addition, the diversity of glomerospores found around roots was also assessed.

\section{Materials and methods}

\section{Study area}

At the boundary between the second and third Paranaense plateaus is a transitional vegetation between mixed rain forest and semideciduous forest. The vegetation comprises, simultaneously Araucaria angustifolia (Bertol.) Kuntze (Araucariaceae), Dicksonia sellowiana Hook. (Dicksoniaceae) and large volume of epiphytes, characteristics of mixed rain forest in addition to Aspidosperma polyneuron Müll. Arg. (Apocynaceae), Bougainvillea glabra Choisy (Nyctaginaceae) and Cabralea canjerana (Vell.) Mart. (Meliaceae), typical species of the semideciduous forest (Medri et al. 2002; Dettke et al. 2008). This vegetation formation has an irregular canopy between 15 and $20 \mathrm{~m}$ and emergent trees up to $30 \mathrm{~m}$, whose trunks have thick bark and sustain robust branches and a large, sparsely branched canopy (Veloso 1992). In the treeshrub understory, there is an herbaceous layer where herbs, ferns, palms and epiphytes are scarce (Torezan 2002).

Located on the banks of the Tibagi River, the study area covers the municipalities of Telêmaco Borba (24⒈' $28^{\prime \prime}$

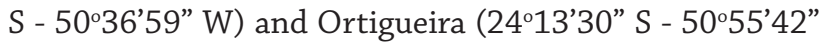
$\mathrm{W})$, in the central-eastern region of the state of Paraná, at 1,150 m elevation, inside a transition zone between the subtropical and tropical climate $(\mathrm{Cfa} / \mathrm{Cfb})$, with averages annual temperatures and rainfall of $19.5^{\circ} \mathrm{C}$ and $1700 \mathrm{~mm}$, respectively (Mendonça \& Danni-Oliveira 2002). The forest responds to the seasonal rhythm and in the unfavorable period of the year, the canopy trees shed their leaves, resulting in greater variation and light availability for the understory species, which affects the forest dynamics (Gandolfi 2003).

\section{Plant collection and field data recovery}

Plants were collected randomly within three years (20112013), mainly during spring and summer (September to March). Pteridophytes were carefully removed from the phorophyte using a knife. Information regarding to locality and environmental features where epiphytes were found, was noted. Four specimens of each species were collected in different sites/phorophytes along the area. These were placed in individual plastic bags and taken to laboratory, where the roots were separated from the rhizomes with the aid of a razor blade and preserved in $70 \%$ alcohol for nearly one month. Rhizomes and leaves were herborized and two species of lycophytes and nine of ferns were identified by 


\section{Arbuscular mycorrhizal and dark septate fungi are not common in roots of epiphytic pteridophytes of a transitional forest area in South Brazil}

Paulo Henrique Labiak Evangelista (Universidade Federal do Paraná). After that, the plants were submitted at the Herbarium of the Universidade Estadual de Maringá (HUEM). Table 1 summarizes information on the plant species investigated.

\section{Evaluation of root colonization by AMF and DSF}

The roots were washed in water, and then cleared in $10 \% \mathrm{KOH}$, acidified with $5 \% \mathrm{HCl}$ and stained with trypan blue (Phillips \& Hayman 1970). Initially, an assessment was made of the roots under a stereoscopic microscope, and the segments where there were points of fungal colonization were separated and observed under light microscopy. The number of points was recorded and the characteristic AMF (intra-radical hyphae, extra-radical hyphae, vesicles, and arbuscules) and DSF (dark hyphae, hyaline hyphae, microesclerotia) structures were identified. Colonization frequency in the root system (F \%) was estimated according to Trouvelot et al. (1986).

\section{AMF spore isolation and taxonomic identification}

Glomerospores were extracted from $50 \mathrm{~g}$ of substrate near the roots, after natural drying, using the wet sieving technique (Gerdemann \& Nicolson 1963) followed by centrifugation in $50 \%$ sucrose solution (Jenkins 1964). Under a stereomicroscope, only intact and non-parasitized spores were separated and mounted on semi-permanent slides with resin with polyvinyl alcohol-lactic acid-glycerol (PVLG) or PVLG plus Melzer's solution (Morton et al. 1993). After mounting, the slides were kept in a drying oven $\left( \pm 50^{\circ} \mathrm{C}\right)$ for thirty hours.

Taxonomical identification was based on morphological characteristics of the spores and their wall layers composition, both observed under light microscopy. Original descriptions available on the Arthur Schüßler's website (http://www. amf-phylogeny.com/) and descriptions contained on the International Culture Collection of (Vesicular) Arbuscular Mycorrhizal Fungi (https://invam.wvu.edu/) and Department of Plant Pathology, University of Agriculture Szcezin (http://www.zor.zut.edu.pl/Glomeromycota_2/ Home.html) were used as support to identify the species.

\section{Statistical analysis}

Data were initially evaluated for linearity (visual inspection of residues), normality (Shapiro-Wilk) and homoscedasticity (Levene). As the data did not met the assumptions for parametric statistical analysis, they were subjected to a spearman correlation coefficient analysis. The adopted degree for significant differences was $5 \%$.

Table 1. Epiphytic lycophytes and ferns collected from a transitional area of Mixed Forest and Semidecidual Forest in South of Brazil and some morphological and ecological data. Plants are deposited at the herbarium of the Universidade Estadual de Maringá (HUEM)*.

\begin{tabular}{|c|c|c|c|c|c|}
\hline \multirow{2}{*}{$\begin{array}{l}\text { Pteridophytes } \\
\text { Family/Species }\end{array}$} & \multicolumn{4}{|c|}{ Phorophyte } & \multirow{2}{*}{ Environment } \\
\hline & Voucher* & Stem/Root & Group $^{1}$ & Position & \\
\hline \multicolumn{6}{|l|}{ Aspleniaceae } \\
\hline Asplenium gastonis Fée & 20367 & erect/wiry & holoepiphyte & $\begin{array}{l}\text { median trunk, inner } \\
\text { crown }\end{array}$ & $\begin{array}{l}\text { shade, partial } \\
\text { light }\end{array}$ \\
\hline \multicolumn{6}{|l|}{ Lycopodiaceae } \\
\hline Phlegmariurus mandiocanus (Raddi) B. Øllg. & 20388 & erect/wiry & C-holoepiphyte & $\begin{array}{l}\text { lower trunk, median } \\
\text { trunk }\end{array}$ & shade, humid \\
\hline \multicolumn{6}{|l|}{ Polypodiaceae } \\
\hline Campyloneurum aglaolepis (Alston) de la Sota & 24266 & short-creeping/wiry & holoepiphyte & $\begin{array}{l}\text { median trunk, inner } \\
\text { crown }\end{array}$ & shade, humid \\
\hline Campyloneurum nitidum (Kaulf.) C. Presl & 24249 & short-creeping/wiry & F-holoepiphyte & $\begin{array}{l}\text { median trunk, inner } \\
\text { crown }\end{array}$ & shade, humid \\
\hline Microgramma squamulosa (Kaulf.) de la Sota & 20467 & long-creeping/wiry & C-holoepiphyte & $\begin{array}{c}\text { inner crown, outer } \\
\text { crown }\end{array}$ & light, shade \\
\hline Microgramma vacciniifolia (Langsd. \&Fisch.) Copel. & 24248 & long-creeping/wiry & C-holoepiphyte & $\begin{array}{c}\text { inner crown, crown } \\
\text { base }\end{array}$ & light \\
\hline Niphidium crassifolium (L.) Lellinger & 28134 & long-creeping/wiry & C-holoepiphyte & $\begin{array}{l}\text { lower trunk, median } \\
\text { trunk }\end{array}$ & shade, humid \\
\hline Pecluma pectinatiformis (Lindm.) M. G. Price & 24287 & short/long-creeping/wiry & C-holoepiphyte & median trunk & light \\
\hline Pleopeltis hirsutissima (Raddi) de la Sota & 24289 & short-creeping/wiry & C-holoepiphyte & inner crown & light, humid \\
\hline Pleopeltis pleopeltifolia (Raddi) Alston & 24243 & short-creeping/wiry & C-holoepiphyte & $\begin{array}{l}\text { inner crown, median } \\
\text { trunk }\end{array}$ & light \\
\hline \multicolumn{6}{|l|}{ Selaginellaceae } \\
\hline Selaginella microphylla (Kunth.) Spring & 22237 & prostrate/wiry & A-holoepiphyte & lower trunk & shade, humid \\
\hline
\end{tabular}

${ }^{1}$ C: characteristic; F: facultative; A: accidental; according to Bonnet et al. (2011) 


\section{Results and discussion}

Almost all epiphytic species found in this study (except Microgramma vacciniifolia and Niphidium crassifolium) has distribution limited to South America (Michelon \& Labiak 2013). Previous studies had been made in other continents where vegetation and climatic zones are too different. Studies evaluating the presence of AMF and DSF in epiphytic pteridophytes in South America were already made in Argentina (Fernández et al. 2010; Lugo et al. 2018), but in Brazil, despite the high biodiversity and cases of endemism in the most biomes, including Atlantic Forest (Freitas et al. 2016), it is a not reality.
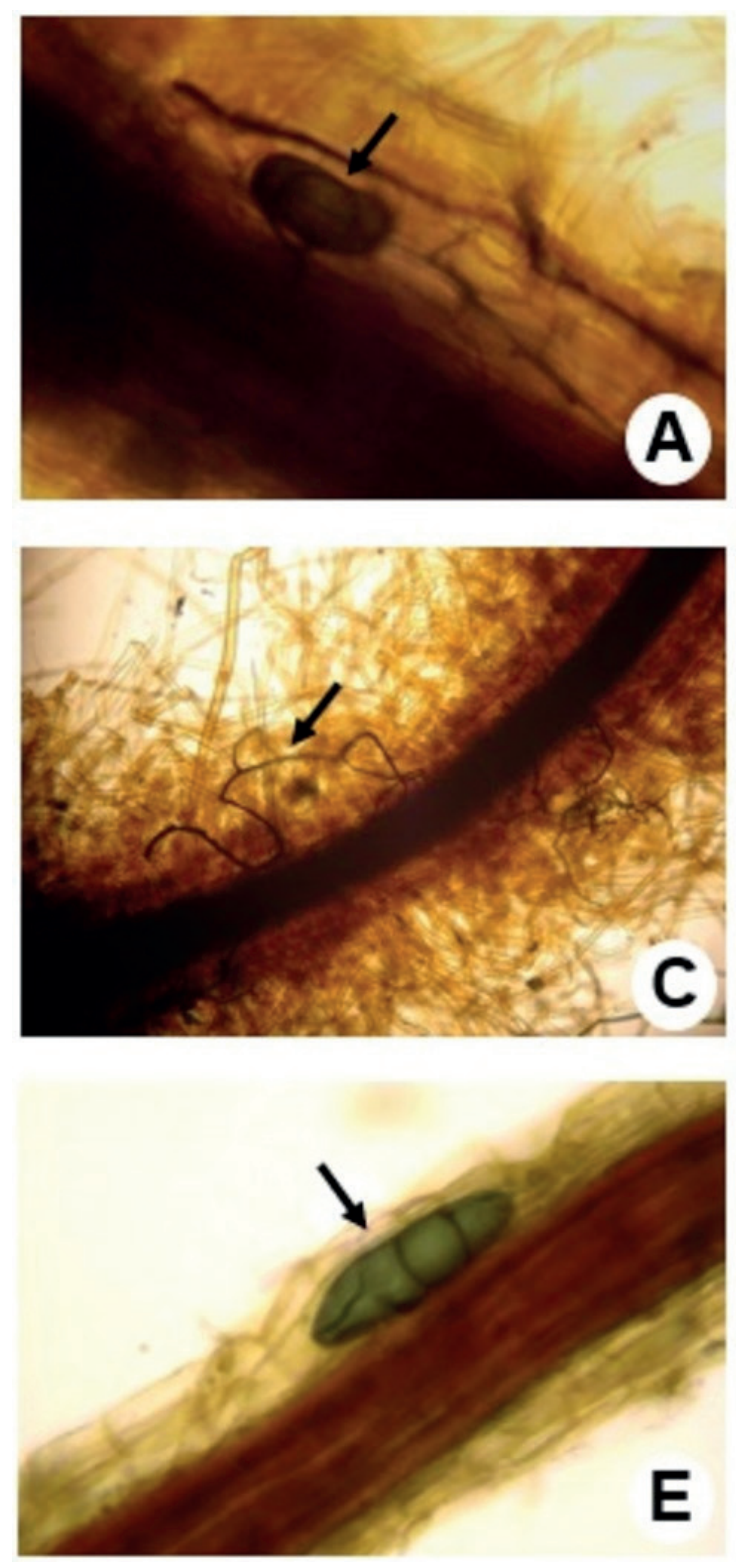

Colonization by AMF and DSF was verified in the selected plants (Fig. 1), with the first group of fungi occurring in a greater number of species than the second. The majority of epiphyte species colonized by the AMF occur associated with the trunk and the internal part of the phorophyte crown (Tab. 1), places used by terrestrial animals that transit between the floor and the canopy, a condition that favors the introduction of mycorrhizal propagules (Lehnert \& Kessler 2016). Five species of epiphytes showed dual colonization and a moderate correlation (Spearman Rank R $=0.51 ; \mathrm{p} \leq$ 0.05) was observed between the frequencies of AMF and DSF in roots. Coexistence of these symbionts are known for all groups of plants, including pteridophytes; nevertheless,
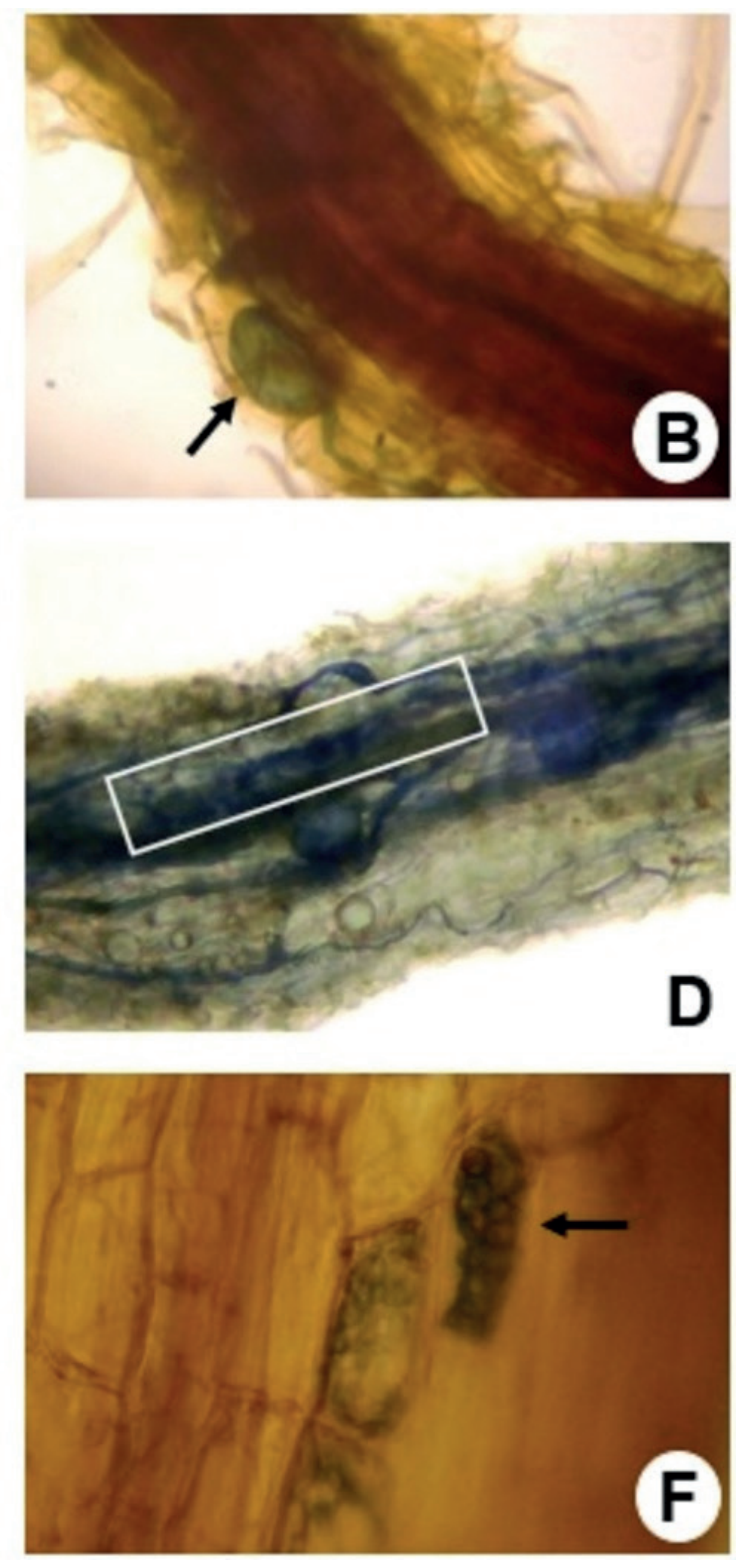

Figure 1. Details (arrows) of root colonization of epiphytic lycophytes and ferns by AMF and DSF. A) acaulosporoid vesicle in Niphidium crassifolium; B) glomoid vesicle in Asplenium gastonis; c) extra-radical hyphae of AMF in Pleopeltis hirsutissima; D) degenerating AMF arbuscules in Niphidium crassifolium; E) and F) microsclerotium of DSF in Pecluma pectinatiformis and Phlegmariurus mandiocanus respectively. 
it is an unusual event in epiphytic lycophytes and ferns (Muthukumar \& Prabha 2013; Muthukumar et al. 2014; Lara-Pérez et al. 2015).

Typical structures of arbuscular mycorrhizal colonization were observed in nine species but not all the examined individuals of a species were colonized (Tab. 2). Considering the frequency of occurrence ( $\mathrm{F} \%$ ), four groups of species were recognized: 1 ) not colonized by AMF (0\%): Microgramma squamulosa, $M$. vacciniifolia); 2) marginally colonized (25\%): Campyloneurum aglaolepis, Pleopeltis pleopeltifolia, P. hirsutissima, Selaginella microphylla); 3) occasionally colonized (50\%): Asplenium gastonis, Pecluma pectinatiformis, Phlegmariurus mandiocanus); widely colonized ( $\geq 75 \%)$ : Niphidium crassifolium, Campyloneurum nitidum).

Extra-radical hyphae linked to the epidermis were observed in five of the nine colonized species; intra-radical hyphae and vesicles were observed in all species colonized. Two vesicle morphologies were detected, acaulosporoid and glomoid (Fig. 1A, B) which matches the groups of AMF species found near the roots (Tab. 2). Arbuscules were not found, although they have been observed in other species of pteridophytes, including epiphytes (Dickson et al. 2007; Muthuraja et al. 2014). In the absence of arbuscules, hyphal coils and arbusculate coils usually transfer nutrients to ferns (Dickson et al. 2007), but these were also not observed in this study. The absence of such structures may indicate that the mycorrhizal symbiosis is or, in that circumstance, was functionally neutral (Brundrett 2009).

The vesicles are usually formed after the arbuscules (Montero et al. 2019), and as these have a half-life ranging from two to twelve days (Gadkar et al. 2001), it is believed that arbuscules were not observed because they had already degenerated. The dark coloration of the roots and the lack of a complete clearing of the cortex (Fig. 1C) may have made it difficult to see the arbuscules, especially if they were in an advanced degree of senescence. In the thinner roots, clearing was more efficient and mycorrhizal colonization could be more easily evidenced. In some regions of these roots, structures resembling degenerating arbuscules were observed (Fig. 1D), but the small incidence of these does not enable us to confirm their identity.

The frequency of the mycorrhizal colonization of the root segments was low, ranging from 3.33 to $16.67 \%$, similarly to the values found by Lara-Pérez et al. (2015), but much lower than those observed in epiphytic lycophytes and ferns of other studies (Fernández et al. 2010; Muthukumar \& Prabha 2013; Muthukumar et al. 2014; Muthuraja et al. 2014). Factors such as availability of infective propagules, root morphology, host plant identity, growth rate and degree of mycorrhizal dependence may have contributed to the low colonization percentages found in this study. The use of different methods (grid-line intersect, root slide technique, magnified intersections) in other studies for assessing root colonization by AMF could also contribute to these differences.

Absence or low frequency of mycorrhizal propagules in the atmosphere are factors that can restrict the establishment of the association. The vertical dispersion of AMF depends on animals, moving from the ground to the canopy (Mangan \& Adler 2002), or wind (Chaudhary et al. 2020), but the second condition is expected to be fairly inefficient inside a forest (Egan et al. 2014). In this inventory, the low number of spores of AMF (Tab. 3) could be due to both the limited entry of propagules into the tree crowns, fact recognized as critical by Muthukumar \& Prabha (2013), and restriction of colonization and sporulation mediated by plants through shortening transfer of photoassimilates to the fungi.

The richness of AMF was modest, and the composition of the communities varied greatly among and within the epiphytic species (Tab. 3). Seventeen species (or morphotypes) were identified, six of acaulosporoid spores and eleven of glomoid spores. Acaulospora aff. lacunosa and Glomus aff. formosanum were present in three host

Table 2. Occurrence of fungal structures and mean percentages of colonization in roots of epiphytic lycophytes and ferns collected from a transitional area of Mixed Rain Forest and Semidecidual Forest in the South of Brazil.

\begin{tabular}{|c|c|c|c|c|c|c|c|c|c|c|c|}
\hline \multirow{2}{*}{ Epiphytes } & \multicolumn{6}{|c|}{ Arbuscular mycorrhizal fungi } & \multicolumn{5}{|c|}{ Dark septate fungi } \\
\hline & FO & AP & IH & VE & AR & $\mathbf{F} \%$ & FO & DH & HH & MC & $\mathbf{F} \%$ \\
\hline Asplenium gastonis & 2 & + & + & + & - & 3.33 & 0 & - & - & - & 0.00 \\
\hline Campyloneurum aglaolepis & 1 & - & + & + & - & 3.33 & 0 & - & - & - & 0.00 \\
\hline Campyloneurum nitidum & 3 & + & + & + & - & 8.89 & 3 & + & - & + & 4.44 \\
\hline Microgramma squamulosa & 0 & - & - & - & - & 0.00 & 0 & - & - & - & 0.00 \\
\hline Microgramma vacciniifolia & 0 & - & - & - & - & 0.00 & 0 & - & - & - & 0.00 \\
\hline Niphidium crassifolium & 4 & + & + & + & - & 8.34 & 0 & - & - & - & 0.00 \\
\hline Pecluma pectinatiformis & 2 & + & + & + & - & 16.67 & 2 & + & - & + & 10.00 \\
\hline Phlegmariurus mandiocanus & 2 & - & + & + & - & 5.00 & 1 & + & - & + & 3.33 \\
\hline Pleopeltis hirsutissima & 1 & + & + & + & - & 6.67 & 0 & - & - & - & 0.00 \\
\hline Pleopeltis pleopeltifolia & 1 & - & + & + & - & 3.33 & 1 & + & - & + & 6.67 \\
\hline Selaginella microphylla & 1 & - & + & + & - & 3.33 & 1 & + & - & + & 6.67 \\
\hline
\end{tabular}

$\mathrm{n}=4$; + presence; - absence; MNS: mean number of spores; FO: frequency of occurrence (when two or more replicates were colonized, means were obtained from these number only); AP: appressorium; IH: intra-radical hyphae; VE: vesicles; AR: arbuscules; DH: dark hyphae; HH: hyaline hyphae; MC: microesclerotia; F \% = colonized number of segments/total number of segments $\mathrm{x} 100$. 
Table 3. Composition of arbuscular mycorrhizal fungi found in the rhizosphere of epiphytic lycophytes and ferns collected in a transitional area of Mixed Rain Forest and Semidecidual Forest in South of Brazil.

\begin{tabular}{|c|c|c|c|c|c|c|c|c|c|c|c|c|c|}
\hline \multirow{2}{*}{ Species of AMF } & \multicolumn{11}{|c|}{ Epiphytes } & \multirow{2}{*}{ TE } & \multirow{2}{*}{ ANS } \\
\hline & $\mathrm{Ag}$ & $\mathrm{Ca}$ & Cn & Ms & Mv & Nc & $\mathrm{Pp}$ & $\mathrm{Pm}$ & Plp & PIh & Sm & & \\
\hline Acaulospora aff. cavernata & - & - & - & - & - & - & 8 & - & - & - & - & 1 & 1 \\
\hline Acaulospora aff. colossica & - & - & - & - & - & - & - & - & 1 & - & - & 1 & 1 \\
\hline Acaulospora aff. gedanensis & - & - & 2 & - & - & - & - & - & - & - & - & 1 & 2 \\
\hline Acaulospora aff. lacunosa & - & - & 1 & - & - & 4 & - & - & - & 16 & - & 3 & 21 \\
\hline Acaulospora morrowiae & - & - & - & - & - & - & 3 & 1 & - & - & - & 2 & 4 \\
\hline Acaulospora sp. (morrowiae like, $\mathrm{M}^{-}$) & - & - & - & - & - & - & 4 & - & - & - & - & 1 & 4 \\
\hline Claroideoglomus aff. candidum & - & - & - & - & - & 1 & - & - & - & - & - & 1 & 1 \\
\hline Claroideoglomus aff. luteum & - & - & - & - & - & - & - & - & - & 2 & - & 1 & 2 \\
\hline Funneliformis aff. geosporum & - & - & - & - & - & - & - & - & - & 1 & - & 1 & 1 \\
\hline Glomus aff. formosanum & - & - & 9 & - & - & 6 & - & - & - & 6 & - & 3 & 21 \\
\hline Glomus aff. rubiformis & - & - & 3 & - & - & - & - & - & - & - & - & 1 & 3 \\
\hline Glomus invermaium & - & - & - & - & - & - & - & - & - & 1 & - & 1 & 1 \\
\hline Glomus macrocarpum & - & - & - & - & 1 & - & - & - & - & - & - & 1 & 1 \\
\hline Glomus sp. (tubaeforme-like) & - & - & S & - & - & - & - & - & - & - & - & 1 & +500 \\
\hline Glomus sp. (inner layer $\mathrm{M}^{+}$) & - & - & 1 & - & - & 1 & - & - & - & - & - & 2 & 2 \\
\hline Glomus sp. (spines in inner layer) & - & - & - & - & - & - & - & - & - & 4 & - & 1 & 4 \\
\hline Glomus sp. (conical pustules) & 21 & - & - & - & - & - & - & - & - & - & - & 1 & 21 \\
\hline Total number of species & 1 & - & 6 & - & 1 & 4 & 3 & 1 & 1 & 6 & - & & \\
\hline Total number of spores & 21 & - & 16 & - & 1 & 12 & 15 & 1 & 1 & 30 & - & & \\
\hline Total number of sporocarps & - & - & 1 & - & - & - & - & - & - & - & - & & \\
\hline
\end{tabular}

TE: total of epiphytes; ANS: accumulated number of spores ( $\mathrm{n}=4)$; Ag: Asplenium gastonis; Ca: Campyloneurum aglaolepis; Cn: Campyloneurum nitidum; Ms: Microgramma squamulosa; Mv: Microgramma vacciniifolia; Nc: Niphidium crassifolium; Pp: Pecluma pectinatiformis; Pm: Phlegmariurus mandiocanus; Plp: Pleopeltis pleopeltifolia; Plh: Pleopeltis hirsutissima; Sm: Selaginella microphylla. M+ = positive reaction to Melzer; $\mathrm{M}^{-}$= negative reaction to Melzer. $\mathrm{S}$ = sporocarp with more than 500 spores.

species, and Pleopeltis hirsutissima and Campyloneurum nitidum were the epiphytes that showed the greatest species richness of AMF (six each). In three species, only one spore was found, which might mean accidental presence. Five other species showed 12 to 30 spore communities, with the highest number of spores occurring in the epiphytes with more weakly colonized roots. Glomus sp. (tubaeforme-like) and Glomus aff. rubiformis produce hundreds of spores in sporocarps and, in this inventory, both were found only in one species, Campyloneurum nitidum.

In an inventory made by Muthukumar \& Prabha (2013), in which they evaluated 54 species of lycophytes and ferns, with different life forms (epiphytes, terrestrial, aquatic and saxicolous) and coming from five sites, a total of nine spores morphotypes (species) of AMF were identified, all belonging to glomoid genera. In our study, spores of Acaulospora are for the first time extracted from substrate around the roots of lycophytes and ferns. Although acaulosporoid vesicles were also observed intraradically, it is not possible to affirm that those spores were formed by the root-colonizing fungi.

Root morphology is considered an important factor in establishing the arbuscular mycorrhizal association in terrestrial plants (Baylis 1975; Manjunath \& Habte 1991). Lycophytes and ferns of epiphytic habit may present two main morphologies, fat and fleshy roots, usually colonized by fungi (AMF, DSF, Mucoromycotina), or thin and wiry roots, less susceptible to association (Pressel et al. 2016). The plants of the present study have roots of the second type, which, in addition to having a smaller diameter and greater mechanical resistance, also have cortical cells impregnated with phenolic compounds and thickened walls (Schneider 2000), which can hinder the entry and formation of intraradical hyphae.

No relation was found between the occurrence of colonization and the taxonomic groups of epiphytes studied. The small sample size may be a reason for that. Lycopodiaceae, Selaginellaceae, Aspleniaceae and Polypodiaceae had roots colonized by AMF and no relationship trend between percentage of root colonization and growth habit (erect, creeping or climbing stems). However, the higher percentages were observed in plants on low trunk, medium trunk and inner crow, regions most likely used by animals dispersing mycorrhizal propagules.

Roots of five species showed intra-radical structures of dark septate fungi (Fig. 1E, F). The frequencies (F \%) of colonization of the root system were low, ranging from 1.67 to $10 \%$ (Tab. 2). Pecluma pectinatiformis was the species with the highest frequency of colonization by DSF, followed by Selaginella microphylla, and Pleopeltis pleopeltifolia. Muthukumar \& Prabha (2013) and Lara-Pérez et al. (2015) did not find DSF in roots of epiphytic ferns and lycophytes. Conversely, Muthukumar et al. (2014) found frequencies that varied from 30 to $80 \%$.

The data from this study show that colonization of epiphytic lycophytes and ferns roots by AMF and DSF is incipient. In the case of AMF, this can result from a 


\section{Arbuscular mycorrhizal and dark septate fungi are not common in roots of epiphytic pteridophytes of a transitional forest area in South Brazil}

low inflow of propagules along the phorophyte just as a low mycorrhizal plant dependency, due to the various mechanisms of adaptation to the air environment. Further, it is the first time that the presence of acaulosporid spores and intraradical vesicles was related to this group of plants.

\section{References}

Barrow JR, Aaltonen R. 2001. A method of evaluating internal colonization of Atriplex canescens (Pursh) Nutt. roots by dark septate fungi and how they are influenced by host physiological activity. Mycorrhiza 11: 199-205.

Baylis GTS. 1975. The magnolioid mycorrhiza and mycotrophy in root systems derived from it. In: Sanders FE, Mosse B, Tinker PB. (eds.) Endomycorrhizas. London, UK, Academic Press, p. 373-389.

Bonnet A, Curcio GR, Lavoranti OJ, Galvão F. 2011. Flora epifítica vascular em três unidades vegetacionais do Rio Tibagi, Paraná, Brasil. Rodriguésia 62: 491-498.

Brundrett MC. 2009. Mycorrhizal associations and other means of nutrition of vascular plants: understanding the global diversity of host plants by resolving conflicting information and developing reliable means of diagnosis. Plant and Soil 320: 37-77.

Cázares E, Trappe JM, Jumpponen A. 2005. Mycorrhiza-plant colonization patterns on a subalpine glacier forefront as a model system of primary succession. Mycorrhiza 15: 405-416.

Chaudhary VB, Nolimal S, Sosa-Hernández MA, Egan C, Kastens J. 2020. Trait-based aerial dispersal of arbuscular mycorrhizal fungi. New Phytologist 228: 238-252.

Chen XM, Dong HL, Hu KX, Sun ZR, Chen J, Guo SX. 2010. Diversity and antimicrobial and plant growth-promoting activities of endophytic fungi in Dendrobium loddigesii Rolfe. Journal of Plant Growth Regulation 29: 328-337.

Chilvers GA, Lapeyrie FF, Horan DP. 1987. Ectomycorrhizal vs. endomycorrhizal fungi within the same root system. New Phytologist 107: 441-448.

Dettke GA, Orfrini AC, Milaneze-Gutierre MA. 2008. Composição florística e distribuição de epífitas vasculares em um remanescente alterado de Floresta Estacional Semidecidual no Paraná, Brasil. Rodriguésia 59: 859-872.

Dickson S, Smith FA, Smith SE. 2007. Structural differences in arbuscular mycorrhizal symbioses: more than 100 years after Gallaud, where next? Mycorrhiza 17: 375-393.

Egan C, Li D-W, Klironomos J. 2014. Detection of arbuscular mycorrhizal fungal spores in the air across different biomes and ecoregions. Fungal Ecology 12: 26-31.

Fernández N, Fontenla S, Messuti MI. 2010. Mycorrhizal status of obligate and facultative epiphytic ferns in Valdivian temperate forest of Patagonia, Argentina. American Fern Journal 100: 1626. doi:10.1640/0002-8444-100.1.16

Fraga LL, Da Silva LB, Schmitt JL. 2008. Composição e distribuição vertical de pteridófitas epifíticas sobre Dicksonia sellowiana Hook. (Dicksoniaceae), em floresta ombrófila mista no sul do Brasil. Biota Neotropica 8: 123-129.

Freitas L, Salino A, Neto LM, et al. 2016. A comprehensive checklist of vascular epiphytes of the Atlantic Forest reveals outstanding endemic rates. PhytoKeys 58: 6579.

Fuchs B, Haselwandter K. 2004. Red list plants: colonization by arbuscular mycorrhizal fungi and dark septate endophytes. Mycorrhiza 14: 277-281.

Gadkar V, David-Schwartz R, Kunik T, Kapulnik Y. 2001. Arbuscular mycorrhizal fungal colonization. Factors involved in host recognition. Plant Physiology 127: 1493-1499.

Gandolfi S. 2003. Regimes de luz em florestas estacionais e suas possíveis consequências. In: Sales VC. (ed.) Ecossistemas brasileiros: manejo e conservação. Fortaleza, Expressão Gráfica e Editora. p. 305-311.
Gemma JN, Koske RE, Flynn T. 1992. Mycorrhizae in Hawaiian Pteridophytes: occurrence and evolutionary significance. American Journal of Botany 79: 843-852.

Gerdemann JW, Nicolson TH. 1963. Spores of mycorrhizal Endogone species extracted from soil by wet sieving and decanting. Transactions of the British Mycological Society 46: 235-244.

Graham EA, Andrade JL. 2004. Drought tolerance associated with vertical stratification of two co-occurring epiphytic bromeliads in a tropical dry forest. American Journal of Botany 91: 699-706.

Jenkins WR. 1964. A rapid centrifugal-flotation technique for separating nematodes from soil. Plant Disease Reporter 48: 692. https://www. cabdirect.org/cabdirect/abstract/1965080110515 May 2020.

Jumpponen ARI. 2001. Dark septate endophytes - are they mycorrhizal? Mycorrhiza 11: 207-211.

Lara-Pérez LA, Valdés-Baizabal MD, Noa-Carrazana JC, Zulueta-Rodríguez R, Lara-Capistrán L, Andrade-Torres A. 2015. Mycorrhizal associations of ferns and lycopods of central Veracruz, Mexico. Symbiosis 65: 85-92.

Lehnert M, Kessler M. 2016. Mycorrhizal relationships in lycophytes and ferns. Fern Gazette 20: 101-116.

Lehnert M, Kottke I, Setaro S, Pazmino LF, Suarez JP, Kessler M. 2009. Mycorrhizal associations of ferns from southern Ecuador. American Fern Journal 99: 292-306.

Lugo AM, Menoyo E, Allione LR, Negritto MA, Henning JA, Anton AM. 2018. Arbuscular mycorrhizas and dark septate endophytes associated with grasses from the Argentine Puna. Mycologia 110: 654-665.

Mandyam K, Jumpponen A. 2005. Seeking the elusive function of the root-colonizing dark septate endophytic fungi. Studies in Mycology 53: 173-189.

Mangan SA, Adler GH. 2002. Seasonal dispersal of arbuscular mycorrhizal fungi by spiny rats in a neotropical forest. Oecologia 131: 587-597.

Manjunath A, Habte M. 1991. Root morphological characteristics of host species having distinct mycorrhizal dependency. Canadian Journal of Botany 69: 671-676.

Medri ME, Bianchini E, Shibatta OA, Pimenta JA. 2002. Bacia do rio Tibagi. Londrina, Câmara Brasileira do Livro.

Mendonça FA, Danni-Oliveira IM. 2002. Dinâmica atmosférica e tipos climáticos predominantes na bacia do rio Tibagi. In: Medri ME, Bianchini E, Shibatta OA, Pimenta JO. (eds.) A bacia do Rio Tibagi. Londrina, Câmara Brasileira do Livro. p. 63-68.

Michelon C, Labiak PH. 2013. Samambaias e Licófitas do Parque Estadual do Guartelá, PR, Brasil. Hoehnea 40: 191-204.

Montero H, Choi J, Paszkowski U. 2019. Arbuscular mycorrhizal phenotyping: the dos and don'ts. New Phytologist 221: 1182-1186.

Morton JB, Bentivenga SP, Wheeler WW. 1993. Germ plasm in the International Collection of Arbuscular and Vesicular-Arbuscular Mycorrhizal Fungi (INVAM) and procedures for culture development, documentation and storage. Mycotaxon 48: 491-528.

Muthukumar T, Prabha K. 2013. Arbuscular mycorrhizal and septate endophyte fungal associations in lycophytes and ferns of south India. Symbiosis 59: 15-33.

Muthukumar T, Sathiyaraj G, Priyadharsini P, Uma E, Sathiyadash K. 2014. Arbuscular mycorrhizal and dark septate endophyte fungal associations in ferns and lycophytes of Palni Hills, Western Ghats, Southern India. Brazilian Journal of Botany 37: 561-581.

Muthukumar T, Senthilkumar M, Rajangam M, Udaiyan K. 2006. Arbuscular mycorrhizal morphology and dark septate fungal associations in medicinal and aromatic plants of Western Ghats, Southern India. Mycorrhiza 17: 11-24.

Muthuraja R, Muthukumar T, Sathiyadash K, Uma E, Priyadharsini P. 2014. Arbuscular mycorrhizal (AM) and dark septate endophyte (DSE) fungal association in lycophytes and ferns of the Kolli Hills, Eastern Ghats, Southern India. American Fern Journal 104: 67-102.

Nervo MH, Andrade BO, Tornquist CG, Mazurana M, Windisch PG, Overbeck GE. 2019. Distinct responses of terrestrial and epiphytic ferns and lycophytes along an elevational gradient in Southern Brazil. Journal of Vegetation Science 30: 55-64.

Phillips JM, Hayman DS. 1970. Improved procedures for clearing roots and staining parasitic and vesicular arbuscular mycorrhizal fungi. New Phytologist 124: 481-488. 


\section{Heloisa Krzyzanski, Maria Auxiliadora Milaneze Gutierre and Rosilaine Carrenho}

Postma JW, Olsson PA, Falkengren-Grerup U. 2007. Root colonization by arbuscular mycorrhizal, fine endophytic and dark septate fungi across a $\mathrm{pH}$ gradient in acid beech forests. Soil Biology and Biochemistry 39: 400-408.

Pressel S, Bidartondo MI, Field KJ, Rimington WR, Duckett JG. 2016 Pteridophyte fungal associations: Current knowledge and future perspectives. Journal of Systematics and Evolution 54: 666-678.

Redman RS, Sheehan KB, Stout RG, Rodriguez RJ, Henson JM. 2002 Thermo tolerance generated by plant/fungal symbiosis. Science 298 : 1581-1584.

Reinert F. 1998. Epiphytes: photosynthesis, water balance and nutrients. In: Scarano FR, Franco AC. (eds.) Ecophysiological strategies of xerophytic and amphibious plants in the neotropics. Rio de Janeiro, Series Oecologia Brasiliensis PPGE-UFRJ. p. 87-108.

Remy W, Taylor TN, Hass H, Kerp H. 1994. Four hundred-million-yearold vesicular arbuscular mycorrhizae. Proceedings of the National Academy of Sciences 91: 11841-11843.

Scervino JM, Gottlieb A, Silvani VA, Pérgola M, Fernández L, Godeas AM. 2009. Exudates of dark septate endophyte (DSE) modulate the development of the arbuscular mycorrhizal fungus (AMF) Gigaspora rosea. Soil Biology and Biochemistry 41: 1753-1756.

Schneider H. 2000. Morphology and anatomy of roots in the filmy fern tribe Trichomaneae H. Schneider (Hymenophyllaceae, Filicatae) and the evolution of rootless taxa. Botanical Journal of the Linnean Society 132: 29-46.
Souza FA, Stürmer SL, Carrenho R, Trufem SF. 2010. Classificação e taxonomia de fungos micorrízicos arbusculares e sua diversidade e ocorrência no Brasil. In: Siqueira JO, de Souza FA, Cardoso EJBN, Tsai SM. (eds.) Micorrizas: 30 anos de pesquisa no Brasil. Lavras, Editora UFLA. p. 15-73.

Taylor TN, Remy W, Hass H, Kerp H. 1995. Fossil arbuscular mycorrhizae from the early Devonian. Mycologia 87: 560-573.

Torezan JM. 2002. Nota sobre a vegetação da bacia do rio Tibagi. In: Medri ME, Bianchini E, Shibatta OA, Pimenta JO. (eds.) A bacia do Rio Tibagi. Londrina, Câmara Brasileira do Livro. p. 103-107.

Trouvelot A, Kough J, Gianinazzi-Pearson V. 1986. Evaluation of VAM infection levels in root systems. Research for estimation methods having a functional significance. In: Gianinazzi- Pearson V, Gianinazzi S. (eds.) Physiological and Genetical Aspects of Mycorrhizal. Paris, INRA Press. p. 217-221.

Veloso HP. 1992. Sistema fitogeográfico. In: Veloso HP, Oliveira-Filho LD, Vaz AMSF, Lima MPM, Marquete R, Brazao JEM. (eds.) Manual técnico da vegetação brasileira. Rio de Janeiro, Instituto Brasileiro de Geografia e Estatística - IBGE. p. 9-38.

Wagg C, Paulter M, Massicotte HB, Peterson RL. 2008. The co-occurrence of ectomycorrhizal, arbuscular mycorrhizal, and dark septate fungi in seedlings of four members of the Pinaceae. Mycorrhiza 18: $103-110$ 